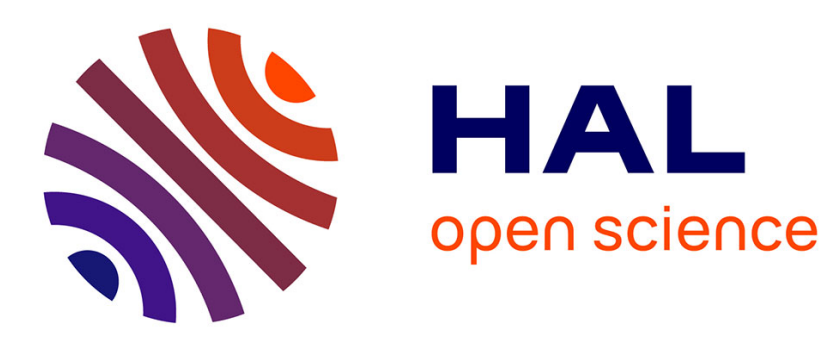

\title{
Thermomechanical fatigue of stainless steels for automotive exhaust systems
}

Pierre-Olivier Santacreu, Laurent Bucher, Alain Köster, Luc Rémy

\section{To cite this version:}

Pierre-Olivier Santacreu, Laurent Bucher, Alain Köster, Luc Rémy. Thermomechanical fatigue of stainless steels for automotive exhaust systems. Revue de Métallurgie, 2006, Janvier, pp.37-42. hal00145071

\section{HAL Id: hal-00145071 \\ https://hal.science/hal-00145071}

Submitted on 27 Mar 2012

HAL is a multi-disciplinary open access archive for the deposit and dissemination of scientific research documents, whether they are published or not. The documents may come from teaching and research institutions in France or abroad, or from public or private research centers.
L'archive ouverte pluridisciplinaire HAL, est destinée au dépôt et à la diffusion de documents scientifiques de niveau recherche, publiés ou non, émanant des établissements d'enseignement et de recherche français ou étrangers, des laboratoires publics ou privés. 
Stainless steel grades are now widely used for automotive exhaust systems, in order to increase their durability. Indeed, the exhaust systems are subjected to ever more severe conditions and they include high technology components such as manifolds, catalytic converters and particle filters. This evolution is a direct consequence of the worldwide effort to decrease automotive pollutant emissions in accordance with the new environmental regulations.

This paper deals with the thermomechanical fatigue (TMF) of stainless steels at high temperature, specially behaviour and damage models, and with the recent progress in the development TMF fatigue design tools using FEA related to the design of stainless steel exhaust manifolds. A numerical method is proposed for the design and the lifetime prediction of stainless steel exhaust manifold under a thermal fatigue load. It includes the modeling of manifolds submitted to the thermal cycle reproduced from motor bench tests. The identification of the constitutive law, in particular the elasto-viscoplastic model, for a wide range of temperatures, provides the most realistic stress-strain response of the structure. Finally, a dedicated damage criterion is proposed on the basis of the maximal temperature and plastic strain amplitude reached during a thermal cycle (modified-Taira model). Identification of a more general damage model on the basis of TMF tests is also discussed.

\section{INTRODUCTION}

As a result of the effort to decrease the pollutant emission of vehicles by catalytic conversion, the temperature of the exhaust gas tends to increase. Therefore, the durability of the exhaust line, especially both corrosion and thermomechanical fatigue (TMF) resistance, need to be improved significantly by the use of stainless steel rather than cast iron. The manifold is the hottest part of the exhaust system, bolted on the motor block to collect the hot burned gas and to feed them into the catalytic converter. Exhaust manifolds are now commonly made of stainless steel bent tubes or stamped shells. The ferritic AISI 409 is the most common grade for exhaust line application but can be used only up to $850^{\circ} \mathrm{C}$. Thus for temperature up to $950^{\circ} \mathrm{C}$, ferritic AISI 441 or $14 \% \mathrm{Cr}-\mathrm{Nb}$ grades are required on account of their improved properties at high temperatures. Austenitic grades AISI 304 or 321 are rarely used because of their poor cyclic oxidation resistance (oxide layer spalling) and of their higher thermal expansion coefficient (1). Thus, only the austenitic refractory grade AISI 308Si (or 302B) can be used at high temperature.

Referring to thermomechanical fatigue, conditions at the exhaust manifold are not recorded throughout the service life of every vehicle, even the histograms of peak temperatures and loads for a large set of drivers are not available. Furthermore, no failed parts have been returned from customer vehicles yet, owing to the recent implementation of stainless steel exhaust manifolds. The motor bench test which is the validation test for acceptance, performed by exhaust makers, is more readily accessible. A typical motor bench cycle is shown in figure 1. Its duration is on the order of 1000 seconds, including a full load period of $400 \mathrm{~s}$ leading to the highest temperature, $900^{\circ} \mathrm{C}$ in figure 1 , and an idle period where the temperature decreases below $600^{\circ} \mathrm{C}$.

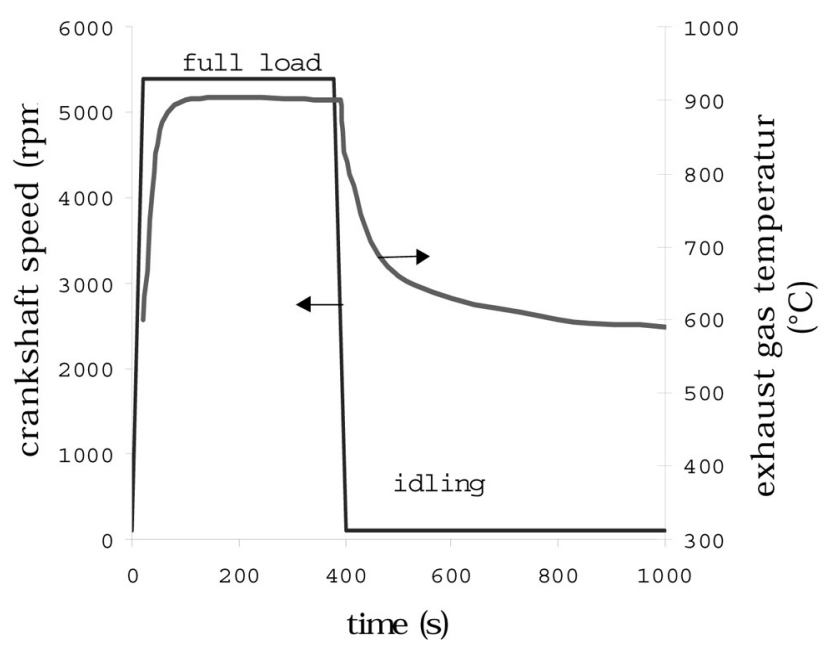

Fig. 1 - Typical motor bench cycle.

Fig. 1 - Exemple de cycle au banc moteur. 


\title{
Fatigue thermomécanique des aciers inoxydables pour échappements d'automobiles.
}

\author{
P. -O. Santacreu (UGINE\&ALZ - Arcelor) \\ L. Bucher, A. Koster, L. Remy (École des Mines de Paris)
}

La température des gaz d'échappement tend à augmenter pour améliorer le fonctionnement des catalyseurs. Les lignes d'échappement sont ainsi soumises à des sollicitations plus sévères, en particulier en ce qui concerne la fatigue thermique. Pour améliorer la durabilité de ces pièces, la fonte a été remplacée par de l'acier inoxydable. Les collecteurs d'échappement subissent les températures les plus élevées. La nuance ferritique AISI 409 est utilisée jusqu'à $850^{\circ} \mathrm{C}$, les nuances AISI 441 ou $14 \% \mathrm{Cr}-\mathrm{Nb}$ jusqu'à $950^{\circ} \mathrm{C}$. Les nuances inoxydables austénitiques, AISI 304 ou AISI 321 présentent les inconvénients d'une faible résistance à l'oxydation cyclique et d'un fort coefficient de dilatation. Les nuances austénitiques réfractaires (AISI 308Si ou 302B) peuvent cependant être utilisées à haute température.

Pour évaluer la sollicitation en fatigue thermique des lignes d'échappement, les essais au banc moteurs constituent la source d'information principale. Ces essais durent 1000 secondes avec des périodes de charge maximale et de ralenti qui provoquent des cycles de température entre 100 et $950{ }^{\circ} \mathrm{C}$. Un collecteur doit pouvoir résister à 1500 cycles pour être accepté en production. La ruine des collecteurs se produit par fissuration accompagnée de striction qui résulte de la déformation plastique locale. On observe aussi des phénomènes d'oxydation, en particulier avec les nuances austénitiques.

Les échappements sont soumis à des cycles de fatigue thermomécanique "déphasés » dont la contrainte maxi- male est appliquée à la température minimale. Un essai de fatigue thermomécanique spécifique a été développé sur une éprouvette en $V$ restreinte mécaniquement et chauffée par effet Joule. La tenue en fatigue thermomécanique ainsi évaluée dépend du maximum et du minimum de température, du temps de maintien à la température maximale et de l'épaisseur de l'échantillon. Les meilleurs résultats sont obtenus avec les nuances ferritiques, AISI 409 et AISI 441.

La modélisation numérique des phénomènes de fatigue thermomécanique requiert une loi de comportement elasto viscoplastique ; c'est le modèle de Chaboche qui est retenu. Le code de calcul ABAQUS est utilisé pour l'analyse numérique des aspects thermiques et mécaniques des essais effectués. Le bon accord entre les efforts sur les mors, à différentes températures, calculés et mesurés, valide la démarche.

Un modèle d'endommagement du type TAIRA, fondé sur une approche de Manson Coffin est proposé pour prévoir la durée de vie des collecteurs. Les résultats sont satisfaisants dans le cas des sollicitations thermo mécaniques déphasées. La simulation des sollicitations en phase est plus délicate, compte tenu de l'apparition d'instabilités mécaniques et de phénomènes de striction.

Le modèle du type TAIRA est maintenant disponible pour la prévision de la durée de vie des collecteurs d'échappement grâce au post-processeur Xhaust-Life développé par UGINE\&ALZ.
The maximal and minimal temperatures depend on the power and stroke of the engine, but they generally range from $100^{\circ} \mathrm{C}$ to $950^{\circ} \mathrm{C}$. An exhaust manifold has to pass approximately 1500 cycles to be considered validated for production; if not, some design improvements or material evolutions are necessary. Fractures observed are characterized by orange peel or necking around the cracks due to plastic deformation and further by multiple cracking. Oxidation is often observed, especially in the case of austenitic grades.

\section{A SIMULATION TEST FOR THERMAL FATIGUE}

A constricted part submitted to a thermal cycle undergoes a typical thermal fatigue process, as illustrated in figure 2. Due to the drop of the mechanical properties of the metal with increasing temperature, accommodation is observed during the first
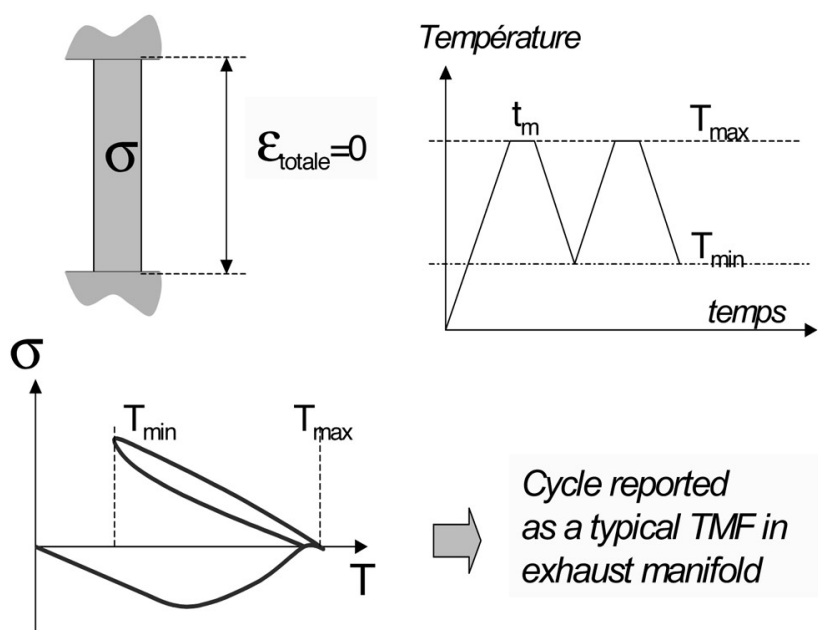

Cycle reported as a typical TMF in exhaust manifold

Fig. 2 - Thermal fatigue process on a constricted part.

Fig. 2 - Mécanisme de fatigue thermique sur une pièce bloquée. 


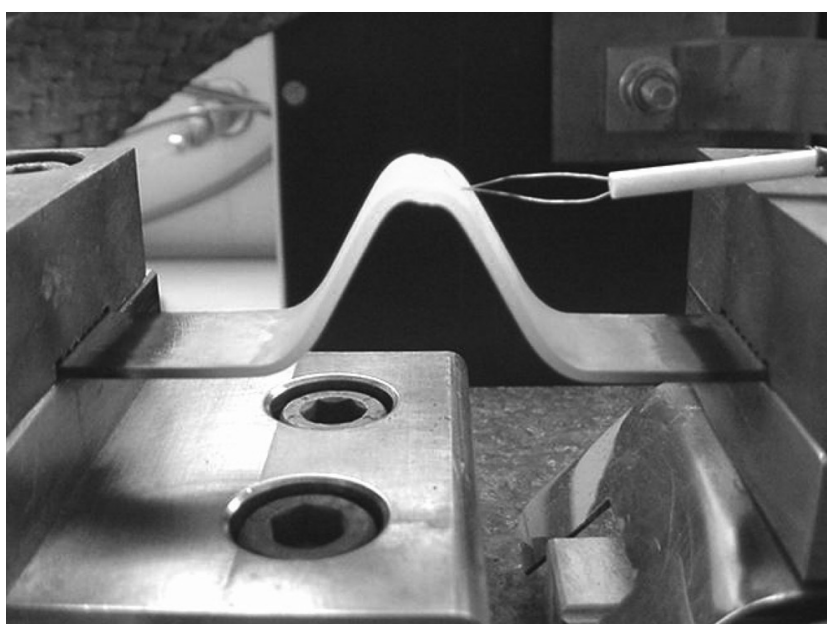

Fig. 3 - Thermal fatigue test developed.

Fig. 3 - L'essai de fatigue thermique développé.

half cycle (first heating) leading to a state of very low stresses at the highest temperature. Subsequent cooling and heating cycles lead to TMF stabilized loops characterized by a maximal tensile state of stress at the lower temperature. We use to designate such cycle by out-of-phase TMF. The experimental adaptation of this principle is quite impossible on thin sheet sample because of buckling of the geometry due to the compressive stress at the first heating. Therefore a dedicated thermal fatigue (TF) test has been developed that permits to apply a thermal cycle on a clamped V-shaped specimen by alternate resistance heating and air-cooling (fig. 3). The thermal fatigue life of a specimen is expressed as the number of cycles to failure. For a given grade, the fatigue life depends on the upper and lower temperatures of the cycle, on the dwell time at the upper temperature and on specimen thickness. The advantage of this test is that it is both simple for ranking the stainless steel grades and representative of the actual thermal fatigue process of an exhaust manifold. Thus, this test makes it possible to study the damage mechanisms $(2,3)$. Some results obtained on the different stainless steel grades in the temperature range $250^{\circ} \mathrm{C}$ $900^{\circ} \mathrm{C}$, for dwell time up to 180 seconds and for $2 \mathrm{~mm}$-thick specimens are presented in figure 4:

- AISI 321 and AISI 304 austenitic grades exhibit a poor thermal fatigue resistance compared to ferritic grades AISI 409, and AISI 441.

- AISI 441 affords the best thermal fatigue resistance, even when compared with the refractory grade AISI 302B that is more sensitive to the detrimental effect of the holding time at the peak temperature.

In fact, microstructure observations performed on specimens revealed that the fatigue crack propagation occurs in intrados of the specimen in the case of ferritic grades and in extrados of the specimen in the case of austenitic grades (fig. 5). The difference between the thermal expansion coefficients of ferritic and of austenitic grades cannot account for the different thermal fatigue lives and crack locations. The following thermal fatigue mechanisms have been observed:

- Fatigue crack at intrados for ferritic grades.

- Fatigue crack, creep cavitation, shape deformation and oxidation at extrados for austenitic grades.

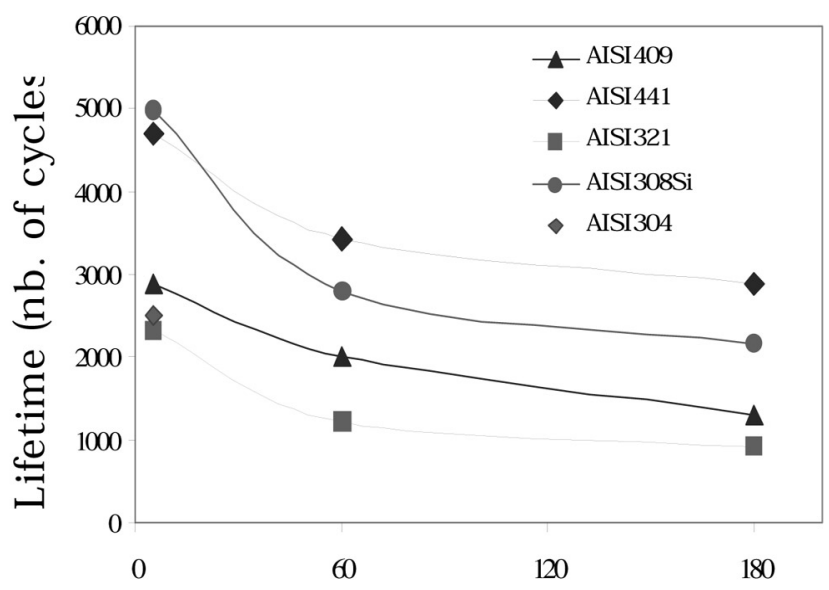

Holding time (s)

Fig. 4 - Thermal fatigue results for $250^{\circ} \mathrm{C}-900^{\circ} \mathrm{C}$ cycles with different dwell times.

Fig. 4 - Résultats de fatigue thermique pour des cycles entre 250 et $900^{\circ} \mathrm{C}$ et différents temps de maintien.
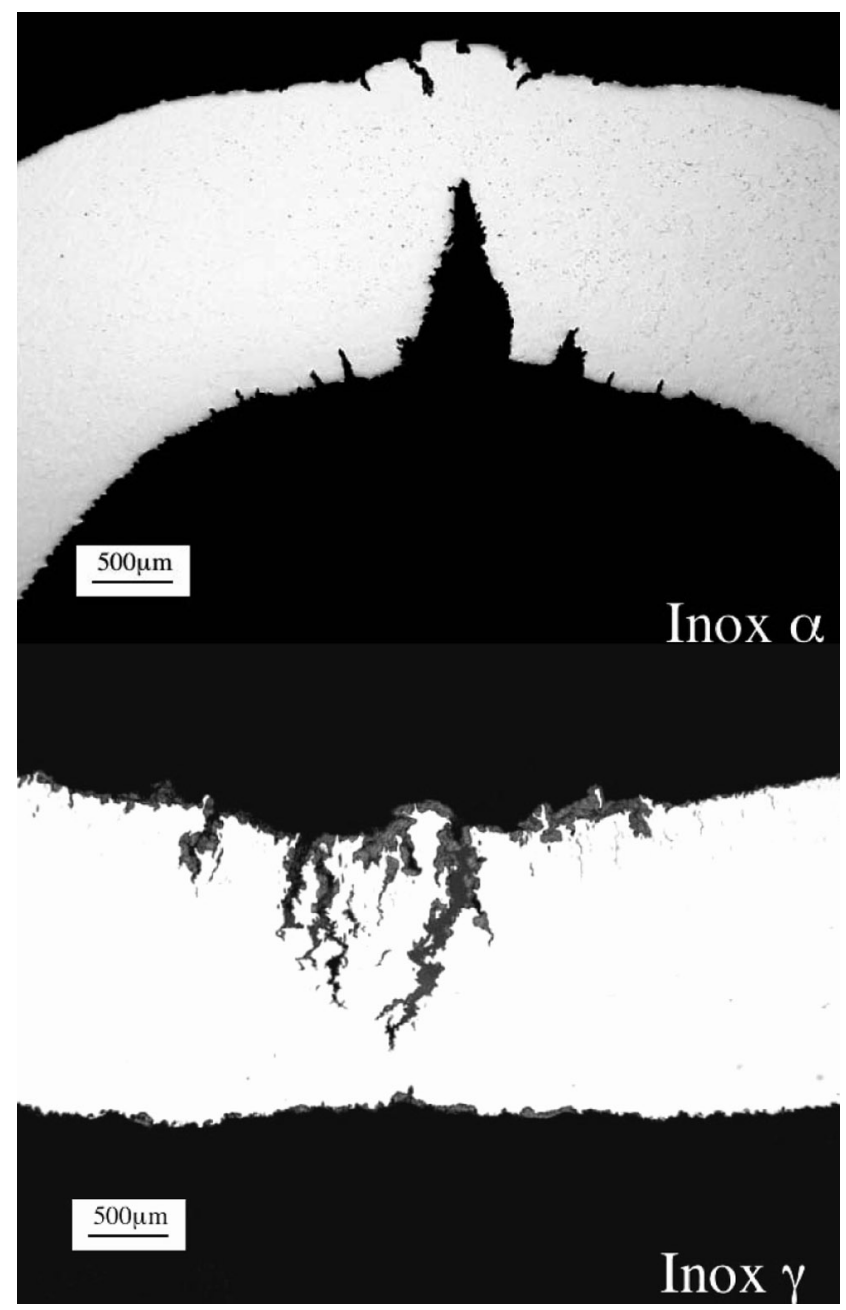

Fig. 5 - Thermal fatigue damage for ferritic ( $)$ and austenitic (Á) grades.

Fig. 5 - Endommagement par fatigue thermique de nuances ferritiques et austénitiques 
Eventually, it must be noted that these results differ significantly from those that are obtained in isothermal conditions, low-cycle or high-cycle fatigue, where resistance generally follows the high temperature tensile strength.

\section{BEHAVIOUR MODEL FOR THERMAL FATIGUE}

\section{Chaboche's elasto viscoplastic model}

In order to simulate numerically the damage of a structural part an accurate behaviour model is essential. Owing to the temperatures involved, an elasto viscoplastic behaviour description has to be preferred to a solely elastoplastic one. In fact, the viscoplastic behaviour of a metal subjected to cyclic loading at high temperature is well-described using a non linear kinematic hardening model coupled with a Norton law; like the model proposed by J.-L.Chaboche (4) and expressed by the followings equations:

Strain partition:

$\varepsilon_{t}=\varepsilon_{t h}+\varepsilon_{e l}+\varepsilon_{p}$

Elastic strain:

$\left.\varepsilon_{e l}=\frac{(1+v)}{E} \sigma-\frac{v}{E} \cdot \operatorname{Tr}(\sigma)\right\rfloor$

Yield criterion:

$$
J_{2}(\sigma-X)-R \geq 0
$$

With X: back stress tensor $\mathrm{R}$ : initial yield strength

and $\mathrm{J}_{2}$ : Von-Mises invariant

Visco-plastic strain

$\stackrel{\circ}{\varepsilon}_{p}=\frac{3}{2} \dot{p} \frac{\sigma^{\prime}-X^{\prime}}{J_{2}(\sigma-X)}$

where $\sigma^{\prime}$ and $X^{\prime}$ are deviatoric tensors of $\sigma$. and X.

$\dot{p}=\left\langle\frac{J_{2}(\sigma-X)-k}{K}\right\rangle^{n}$

$\mathrm{K}$ and $\mathrm{n}$ are viscous parameters.

The back stress $\mathrm{X}$ is described by:

$\dot{X}=\frac{2}{3} C_{\varepsilon}^{\circ} p-\gamma X \stackrel{\circ}{p}$

$\mathrm{C}$ and $\gamma$ are hardening parameters.

All the parameters were assumed to depend only on temperature and are identified using the stress-strain curves derived from low-cycle fatigue tests performed in isothermal conditions, from room temperature to $950^{\circ} \mathrm{C}$, and for different strain amplitudes and rates.

In our identification procedure, fatigue-relaxation and creep tests were also performed to improve the description of long period creep process. Because the stabilised strain-stress loop

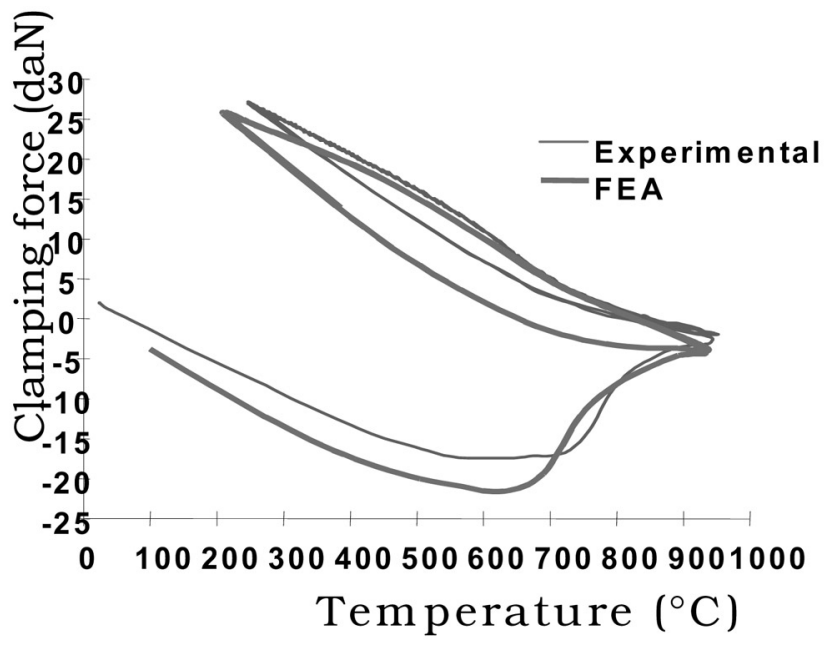

Fig. 6 - Comparison between experiment and FEA of the thermal fatigue test.

Fig. 6 - Comparaison expérience/modèle EF pour l'essai de fatigue thermique.

was chosen for the parameter identification, we supposed that the material reached a saturated cyclic hardening state. It is clear that a complete coupled metallurgical behaviour (precipitation and softening effects) will be a significant improvement for the model but identification and implementation in FE code are substantially more complex.

\section{Application to the FEM of the thermal fatigue test}

The ABAQUS Finite Element software (5) was used as solver for both thermal and mechanical analysis of the different experiments where thickness, maximal and minimal temperatures, holding time and grade were varied. First, the thermal analysis was done to fit precisely the experimental measurements by thermocouples.

A user material procedure was necessary to perform the thermomechanical analysis using the elasto-viscoplastic Chaboche model (6). Different experimental conditions were simulated but, considering the rapid stabilization loop, only the four first cycles are simulated. Figure 6 draws a comparison between the experimental and calculated clamping force, which is considered as a satisfying result in regard of our assumptions. The FE modelling of the TF test permits to analyse the state of strain and stress in the specimen along the duration of the cycle and will help to identify a dedicated TF damage criterion.

\section{DAMAGE MODEL}

\section{Modified Taira's damage model}

Correlation between the number of cycles to failure obtained from the TF test and the amplitude of cumulated plastic strain $\left(\Delta \epsilon_{\mathrm{p}}\right)$ at extrados obtained after a FE analysis of the same test allows to build a predictive model. Indeed, TAIRA (7) propo- 


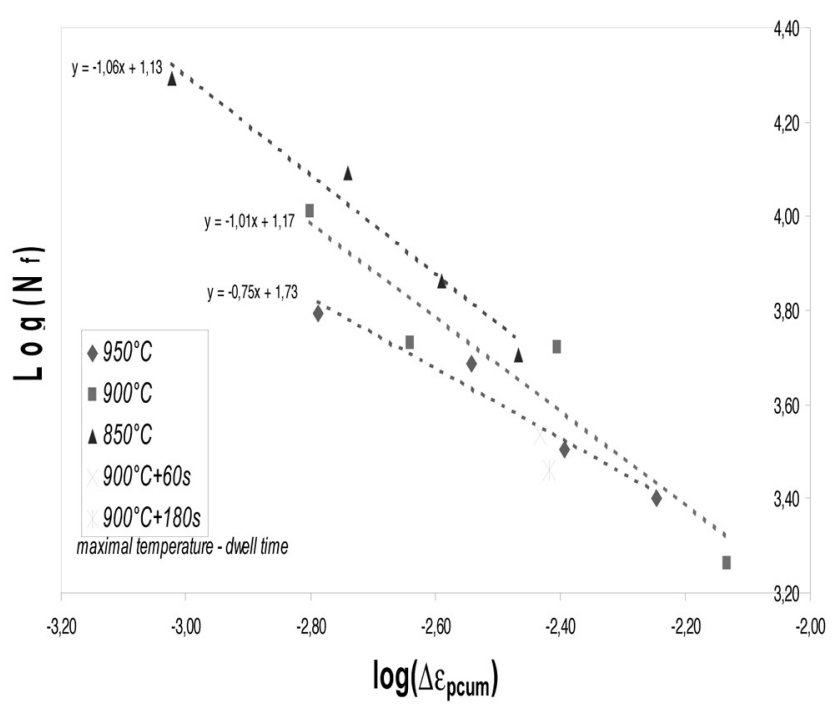

Fig. 7 - Taira curves for AISI 441.

Fig. 7 - Courbes de Taira pour une nuance AISI 441.

sed a relation between thermal fatigue and low-cycle fatigue durability based on a MANSON-COFFIN model:

$\mathrm{N}=\lambda\left(\mathrm{T}_{\mathrm{eq}}\right) \Delta \epsilon_{\mathrm{p}}^{\mathrm{t}}$

$\mathrm{T}$ represents the maximum temperature of the thermal cycle $\left(\mathrm{T}_{\max }\right)$, when $\mathrm{T}_{\max }$ is above a given threshold temperature corresponding to the temperature where diffusion process is a controlling mechanism. Under this threshold, T equals to the mean temperature.

Moreover, according to Taira, $\mathrm{t}$ is expected to be around -1 . In our case, we assumed the exponent $t$ independent of temperature and Teq is a function of the maximal temperature and the dwell time. Given that mechanisms of oxidation and creep are temperature activated in the form of $\mathrm{e}^{-\mathrm{e} / \mathrm{RT}}$, the TAIRA model was modified in the following form:

$\mathrm{N}=\lambda\left(\mathrm{T}_{\mathrm{eq}}\right) \Delta \epsilon_{\mathrm{p}}^{\mathrm{t}}$

where:

$T_{e q}=\frac{T_{\max }}{1-a T_{\max } \ln (1+b \tau)}$

Where $\tau$ is the dwell time, a and b are parameters evaluated from tests.

This predictive model has been evaluated from experimental points at three maximal temperatures $\left(850^{\circ} \mathrm{C}, 900^{\circ} \mathrm{C}\right.$ and $950^{\circ} \mathrm{C}$ ) and for three dwell times up to 180 seconds. Exponent $\mathrm{t}$ was found around to -0.92 (fig. 7).

Although this criterion gives good results, it is not complete enough to be efficient in some cases. Indeed, this model is so far limited to:

- "out-of-phase" mode

- plastic strain range from $10^{-3}$ to $10^{-2}$

- maximal temperature range from $650^{\circ} \mathrm{C}$ to $950^{\circ} \mathrm{C}$.
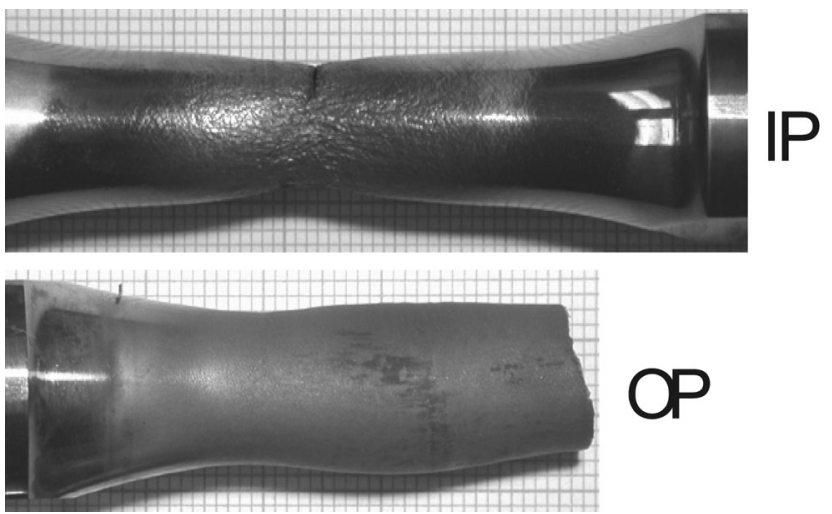

Fig. 8 - Instability effects in thermomechanical fatigue.

Fig. 8 - Instabilités en fatigue thermomécanique.

\section{About thermal fatigue test and more accurate TMF damage model}

The previous described TF test did not permit to study all the phasing effects occurring in a TMF process. More, a FEM is necessary to access to the local stress and strain due to the Vshaped specimen geometry. Therefore TMF tests on tubular cylindrical specimens are now conducted by BUCHER (8) on both $302 \mathrm{~B}$ and 441 grades under axial strain-control in the temperature range $250^{\circ} \mathrm{C}-850^{\circ} \mathrm{C}$.

TMF tests were carried out under in-phase or out-of-phase temperature-mechanical strain cycles. The stress-strain behaviour has been compared with a constitutive Chaboche's model that yields a satisfying description of the macroscopic response. However the determination of the number of cycle to fracture appears more significantly difficult. Indeed, geometric instabilities of specimens occur rapidly and lead to a barrelling or a necking of the specimen for OP or IP TMF respectively (fig. 9). Today, we are not confident that such mode of collapse corresponds to TF damage. This problem appears to be a generic problem when such a high peak temperature is reached $\left(>750^{\circ} \mathrm{C}\right)$ and it is probably due to the very large reduction of flow stress at high temperature and the high strain-rate sensitivity of alloy behaviour. The study is still in progress to simulate the actual TMF damage mechanism on a volume element and to include it into the behaviour model.

\section{CONCLUSION}

\section{Approach applied to the TMF design of exhaust manifold}

An accurate elasto-viscoplastic behaviour model has been identified and is now available to simulate the stresses and strains in a part submitted to thermal fatigue $(9,10)$. The modified Taira predictive model is now available through a post-processor developed by UGINE\&ALZ and named Xhaust-Life. Results of the TMF analysis can be visualized using the ABAQUS viewer. The database of Xhaust-life includes parameters for AISI 441 (1.4509), AISI 308Si 
(1.4828) and new $14 \% \mathrm{Cr}-\mathrm{Nb}$ grades. It has been tested successfully on real manifolds with our customers (fig.9). The use of a virtual thermomechanical fatigue design approach permits to optimise the design of the manifold and limits both the number of prototype and motor bench tests and eventually reduces the risk of failure.

\section{Perspectives}

The modified-Taira model is a phenomenological model that is very satisfactory with ferritic grades. We know though that it is limited to particular TMF situations. Therefore, study is in progress to develop a more physical damage model, including explicitly creep and oxidation processes, on the basis of TMF tests performed on cylindrical uniaxial specimens. The challenge is to bypass the instability effects in TMF due to the very large reduction of high temperature mechanical properties of the considered alloy behaviour at $\mathrm{T}>750^{\circ} \mathrm{C}$.

\section{REFERENCES}

(1) ANTONI (L.), HERBELIN (J.-M.) - EFC working party report on cyclic oxidation of high temperature materials : mechanisms, testing methods, characterisation and lifetime estimation, M. Schütze, W.-J. Quadakkers Eds, publication $\mathrm{n}^{\circ} 27$ in European federation of corrosion series, Institute of Materials, p.187, 1999.

(2) SASSOULAS (H.), SANTACREU (P.-O.) - $18^{\text {ème }}$ Journées de printemps, Commission de Fatigue des Matériaux, Dimensionnement en fatigue des structures: démarches et outils, p.161, Société Française de Métallurgie et de Matériaux SF2M, Paris, 2-3 Juin 1999.

(3) SANTACREU (P.-O.) - Third international congress on thermal stresses, Thermal Stress' 99, Cracow, Poland, J. -J. Skrzypek and R. -B. Hetnarski Eds., p. 245, June 13-17, 1999.

(4) LEMAITRE (J.), CHABOCHE (J. -L.) - (1985), Mécanique des matériaux solides, Dunod Eds., Paris, 1985.

(5) Abaqus, Hibitt, Karlsson and Sorensen, Inc, 1988.

(6) Northwest Numerics and Modeling Inc. and École des Mines de Paris, Z-Set /Z-Aba, version 8 handbook, 1999.

(7) TAIRA, (S.) - Fatigue at elevated temperatures, ASTM STP 520, ASTM, p. 80-101, 1973.

(8) BUCHER (L.) - (2003), Thermomechanical fatigue behaviour of stainless steels for automotive components, 5th international conference on low cycle fatigue (LCF5), Berlin (to be published), 9-11 September 2003.

(9) Lifetime prediction on stainless steel components under thermal fatigue load, $9^{\text {th }}$ International Spring Meeting , temperature-fatigue interaction, p.393-402, 2001.

(10) SIMON (C.), SANTACREU, (P. -O.) - Lifetime prediction of exhaust manifold in TMF, C. Simon and P.-O. Santacreu, roc.CAMP2002, High temperature Fatigue, Eds. G. Ballias, p.257-267, 2002.

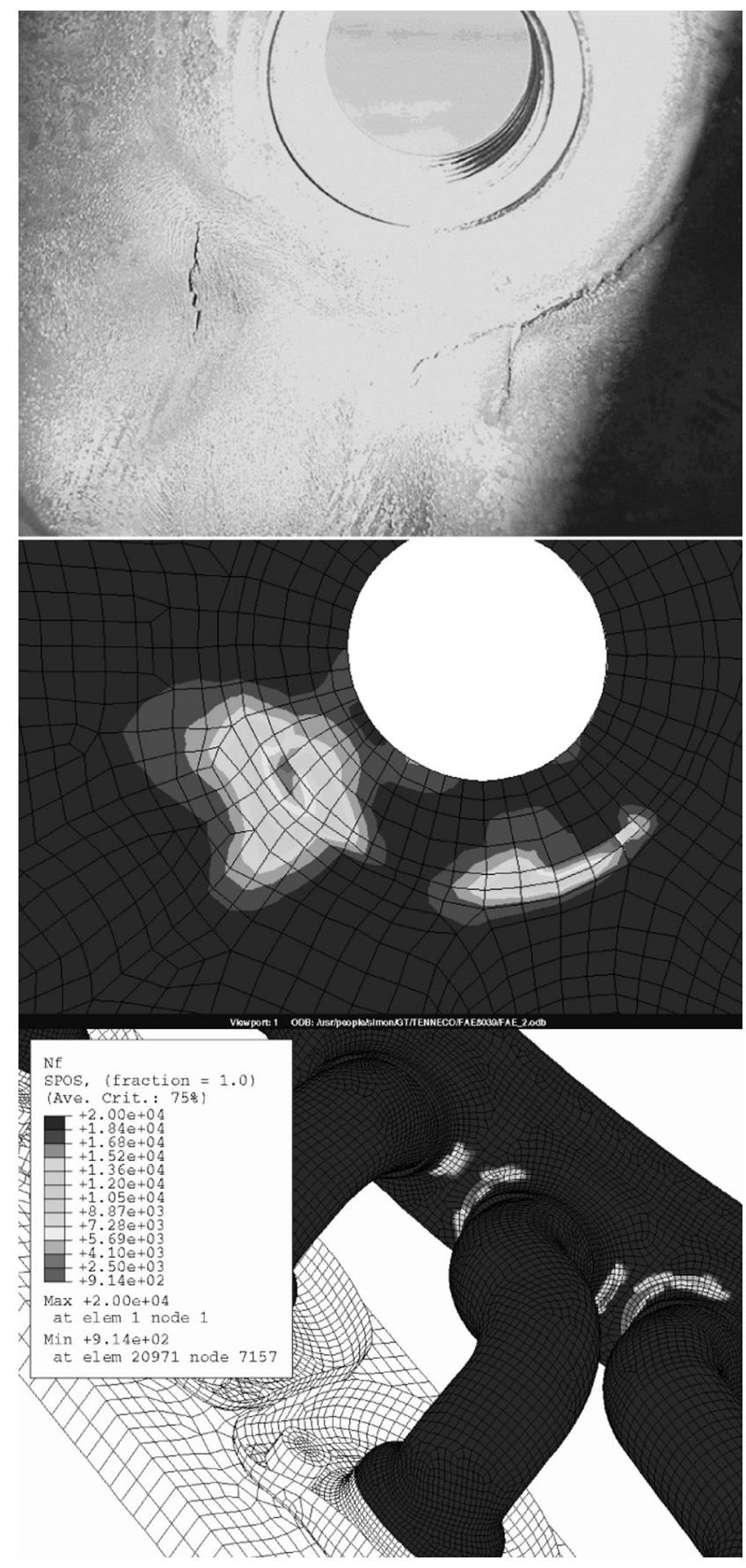

Fig. 9 - Thermal fatigue damage / lifetime prediction on exhaust manifolds.

Fig. 9 - Prévision de l'endommagement et de la durée de vie de collecteurs d'échappement soumis à de la fatigue thermique. 